\title{
The Processes for Creating Value in Natural Food Production in Contemporary Turkey*
}

\author{
Bermal Küçük' ${ }^{10}$
}

\begin{abstract}
Turkey has a niche market based on healthy food consumption that has expanded over the last two decades. This has set the ground for a third sector, the noncertified natural food production that is separate from Certified Organic (CO) and Good Agricultural Practices (GAP). This study examines the value creation mechanisms in Turkey's natural food production, revealing that women's knowledge and labor and various discursive strategies appear as the fundamental elements for creating value in the sector. I argue that the creation and dissemination of a particular discourse about natural foods are just as significant as the material production of such food in creating value and accumulating capital. While material production is realized by appropriating women's labor and knowledge, discursive production is achieved by romanticizing the past. This study is based on empirical data retrieved from a private-run farm located in the Nazilli district of Aydın, Turkey. I conduct in-depth interviews with the owner of the farm and the employees from diverse hierarchical positions. This study is also based on a basic content analysis of the narratives that circulate on the farm's webpage and email group for trust-building.

Keywords: Women's labor • Women's knowledge $\bullet$ Capital accumulation $\bullet$ Natural food production $\bullet$ Noncertified agricultural production $\bullet$ Discourse
\end{abstract}

\footnotetext{
* This paper is abbreviated from my master's thesis "Labor and Value Creation Processes in the Sector of Natural Food Production in Turkey" in 2016

- The name of the farm and the owner will not be explicitly referred to throughout the text due to ethical concerns.

1 Correspondence to: Bermal Küçük, Sociology Department, Graduate School of Social Sciences and Humanities, Koç University, Rumelifeneri Yolu, Sarıyer, İstanbul 34450 Turkey. Email: bkucuk16@ku.edu.tr ORCID: 0000-0002-5481-7687

To cite this article: Küçük, B. (2020). The processes for creating value in natural food production in contemporary Turkey. istanbul Üniversitesi Sosyoloji Dergisi, 40, 109-127. https://doi.org/10.26650/SJ.2020.40.1.0004
} 
This study examines the role women's knowledge and labor and various discursive strategies have in creating value and accumulating capital in Turkey's noncertified natural food production. As in many other parts of the world, Turkey's demand for healthy food has been growing remarkably as a response to the harmful effects of industrialized agriculture over the last decades. Many people in Turkey have become more anxious as ecologists and scientists warn about the toxic substances in industrial food and the diseases they cause. As the detrimental effects of industrial agriculture hold an essential place on the agenda for both ecological movements and individuals, capitalism has responded with green issues and changes in consumer tastes. Hence, a new round of accumulation and niche marketing has emerged based on food quality, safety, biological and cultural diversity, animal welfare, and environmental pollution (Friedmann, 2005). The new round of accumulation in agriculture manifests itself in the form of organic and post-organic food markets, respectively. Organic agriculture has been prominent as an alternative to industrial agriculture since the 1960s in the USA and the 1990s in developing countries, including Turkey. However, a reaction has arisen to the organic market as organic standards impoverish small producers and require the use of "allowable inputs" that lead to abandoning heritage seeds and methods (Goodman \& Goodman, 2007, p. 24; Buck et al., 1997, p. 8; Guthman, 1998; Jordon $\&$ Shuji, 2004). Consequently, a post-organic movement has emerged as the new niche market. Since then, the organic and post-organic movement has begun to dominate the alternative market simultaneously in the Global North and in some developing countries, including Turkey.

Turkey has witnessed both producers' transition from industrial to organic and post-organic agriculture as well as the emergence of new actors in the market who take a share from this niche. These producers consist of those who practice certified or noncertified agriculture. Certified agriculture involves organic production and Good Agricultural Practices (GAP). By following the procedures certification companies impose, organic and GAP producers obtain certification for a certain fee. The document, which knowledgeable consumers have come to trust, provides evidence for the quality and legitimacy of their products (Guthman, 1998). Meanwhile, noncertified organic producers do not go through a certification process in order to distance themselves from the global organic food chain and its monopolization that imposes standardized agricultural methods, techniques, and seeds. These noncertified producers are, however, far from homogeneous. A broad range of actors coexists with different interests and concerns. Nevertheless, I can roughly divide them into two analytical categories: (a) private-run farms that offer natural village products without organic certification and (b) alternative food initiatives that pursue their sustainability and organize around the principles of collectivity and participatory concerns rather than commercial-based logic (Soysal Al \& Küçük, 2019, pp.176-177). This paper focuses explicitly on the private-run farms that appear in the market as natural food providers who are not 
involved in any certification processes. Private-run farms constitute an interesting case for understanding how the pursuit of profit-making paradoxically intertwines with the discourse of locality, collectivity, and sustainability.

Private-run farms have expanded since the 2000s and in Turkey are clustered along the west coast in particular. They position themselves as neither organic nor industrial food providers, instead defining themselves as being engaged with catering to different varieties of natural foods, ranging from fresh products to artisanal cheeses. In this sector, the notion of natural is a blurred category to which producers assign their meaning. This term frequently interchanges with words such as local, alternative, and traditional. Yet, rejecting the requirements imposed by the global organic food chain is a common theme among producers. According to these producers, certified organic foods are unnatural, as the seeds and agricultural techniques are determined by global certification companies instead of the producers themselves. For these producers, food products are natural only if they are produced by local villagers using the heirloom seeds and heritage farming that pass down from previous generations. Hence, the notion of naturalness refers to concepts like localness, or authentic rural life, which is perceived opposite industrial applications. The second important feature these farms have is that their employees are mostly women. Finally, they are run by urban-raised, educated, middle-class entrepreneurs capable of developing a language that can satisfy the sophisticated tastes of their middle- and upper-middle class consumers. These entrepreneurs mostly produce in a rural area and target consumers in urban centers based upon online shopping orders.

The central questions of my research are as follows: If the farm owners reject certifying their products, how do they assure the quality and reliability of their products? And how do these mechanisms facilitate value creation in the sector? To explore these questions, I chose a farm located in the Aegean region as a case study. The farm that this paper is based on possesses some empirical characteristics of the sector. Firstly, it is one of the fastest-growing and leading agricultural organizations in the market of noncertified food production. Its production capacity, product range, number of employees, and widespread appeal to urban consumers have grown significantly since its establishment.

This study is based primarily on two distinct methodological axes: ethnographic research and discourse analysis. The ethnographic research that I conduct in the village where the farm was located occurred in November 2014 and in April 2015 (20 days in total) and consists of my involvement in the production process in the farm's diverse units as a participant-observer and of an in-depth interview with the farm owner, the farm's office workers (agricultural engineer, manager, and the employees who receive and implement orders), and the 15 workers in production. This enabled me to grasp 
the ways the owner defines her mission in the sector and the organizational structure of the production and distribution processes, including division of labor and workers' working conditions and experiences. I also analyzed the discourses and narratives the owner created to promote her products through diverse online channels such as by email and the farm's Internet page. I am included in the email group, to whom she delivers a list of products (with their prices) for that particular week and a diverse narrative about her production methods. The narratives appraise the ethical values implicit in her production methods and the reliability of her products with a constant emphasis on her priority on human health unlike others whose concern is profit-making (Küçük \& Soysal Al, 2019, p.181). The narratives also deal with the practices external to her production procedures (e.g., the sincere relationships she builds with her employees and the rest of the villagers) and proper forms of motherhood, consumption, and nutrition practices as well as of our relation to nature. By grasping the recurrent and prominent themes in the narratives, I attempt to understand how she creates value. Based on the field research at the farm, I argue the creation and dissemination of a particular discourse about natural foods to be as significant as the material production of such food in creating value and accumulating capital. While material production is realized by appropriating women's labor and knowledge, discursive production is accomplished by romanticizing the past.

Alternative agriculture has experienced remarkable growth in the world, especially after the 2000s. Organic farming is one of the fastest-growing segments of alternative agricultural production. A range from small farmers to agribusinesses who hold very different concerns and powers coexists in the organic sector (Cáceres, 2005). The growth in organic agriculture has led to the literature that focuses on consumption and production processes in the sector. The literature that specifically addresses the production aspect primarily discusses how the fees charged by certification companies exclude small farmers from the market and have set the ground for the domination of agro-food companies trying to create an economic niche (Guthman 1997). However, this literature does not discuss what kinds of strategies these small producers have developed as a response to the exclusion mechanisms. Only a few studies have paid attention to the channels small farmers create. Cáceres' (2005) research investigates how small organic farmers in Argentina are unable to become certified farmers because of the high prices. This, Cáceres argued, has led small producers to transform into noncertified organic producers who continue to meet the requirements of organic agriculture. Conversion to noncertified organic agriculture has provided resource-poor farmers with some more advantages as they continue to produce, consume, and sell organic products; improve their food safety; and develop a more environmentally friendly approach to farming (p.139). Cáceres's study shows noncertified organic agriculture to be an opportunity for resource-poor farmers. 
In Turkey, however, noncertified production appears mostly as an opportunity for economically capable entrepreneurs rather than small producers. Turkey has many agricultural entrepreneurs who adopt noncertified production to create authenticity and locality, which enables them to increase the commodity's value. They claim that the standardized rules imposed by the organic sector divert production from locality and authenticity. Such a claim turns into a mechanism for creating value in the sector. Hence noncertified production in Turkey does not always result from poverty, as Caceres argued, rather it emerges as a conscious strategy of economically capable producers. This article wishes to contribute to the literature by taking the capital owner entrepreneurs and their strategies for value creation into account by providing a case study from Turkey. In so doing, I also contribute to the literature in Turkey, where little attention has been paid to the issue. Only Soysal Al (2017) had provided an excellent investigation by focusing on mothers' various alternative food practices, which they describe as their everyday organic food-work. Soysal Al addressed how most economically privileged mothers incrementally show more demand and trust for the noncertified farm products provided online as opposed to certified organic products. However, her study only addressed the consumption aspect of the organic sector while disregarding the production aspect. This production aspect had not become the object of inquiry until recently with Küçük and Soysal Al's (2019) published study. Küçük and Soysal Al's study offers cases from the organic and post-organic markets by examining how producers' discursive repertoire influences consumers' food choices. ${ }^{1}$ This article wishes to complement Küçük and Soysal Al's study by focusing on the material production in the natural food market that specifically manifests itself through women's labor and knowledge.

In the first part of the paper, I aim to highlight the historical conditions under which the rural transformation both in Turkey and across the world has become an important force behind the emergence of such farm-based natural food initiatives. I will follow with a detailed account of the relation and organization of production within the farm. After providing a historical framework, I will focus on the material production of food. To this end, I will draw attention to the literature that discusses the role of woman's domestic labor in capital accumulation in order to better understand the rapid growth of the farm that is my case study. In the last section of the paper, I discuss what I define as the discursive production of food. Unlike material production, the discursive production of food is surrounded by various symbolic images and discourses to make a distinction in the healthy food market. In this section, I unpack these diverse discursive strategies and symbolic images.

1 The scope of this study is not limited to the producer's discursive repertoire on food reliability. See Al, I. S., \& Küçük, B. (2019). In between anxiety and hope: Trusting an alternative among 'alternatives' in the (post) organic food market in Turkey. The International Journal of Sociology of Agriculture and Food, 25(2), $173-190$. 


\section{The Neoliberal Transformation of the Village Hosting the Farm}

Although the neoliberal transformation of Turkish agriculture traces back to the early 1980s, its destructive and brutal face began to appear dramatically after the 2000s in particular. The Agrarian Reform Implementation Project (ARIP) in 2001, as part of the agricultural reform practice of the World Bank, was an important milestone in further liberalizing the agro-food sector in Turkey. The primary purposes of this agreement were to replace the price and input subsidies provided by the state with a new support system, to remove agricultural incentive loans, to privatize state economic enterprises, and to reorganize sale cooperatives (Keyder \& Yenal, 2013, pp. 59-60). Structural adjustment policies gradually removed state monopolies in food production, paving the way for the private sector to become an important actor in food production. This has led to the gradual exclusion and impoverishment of Turkey's small-scale producers in agricultural production. My fieldwork has revealed the emergence of the study's case farm in that particular village to be directly related to these exclusionary processes in Turkey's rural areas. In other words, the early 2000s are when the neoliberal processes in agriculture reached their highest levels and when the post organic market and private-run farms began to simultaneously emerge.

The study's case farm was established in one of the villages of the town of Nazilli in Aydın Province in 2004. The village has 240 households with a population of 2,500. The main agricultural activities include animal husbandry and olive, vegetable, and fruit production. The villagers used to sell these products either to traders or in the local district bazaars at low prices, especially after losing their power to compete with supermarkets as a consequence of declining state support in the era of neoliberalism. The expansion of supermarkets has had considerable impacts on producers' economic conditions by transforming manufacturing into a corporate-led structure where buyer corporations have radically restructured food production relations (Gereffi, Humphrey, \& Sturgeon, 2005; Burch \& Lawrence, 2007; Dixon, 2007; Reardon, Appel, \& Hassler, 2013). In the context of the supermarket revolution (Reardon \& Hopkins, 2006), conventional retailer channels and agricultural production have been transformed to favor supermarkets. These transformations have emerged in parallel with the economic liberalization and domination of foreign entrepreneurs in the agro-food sector in developing countries, including Turkey. In Turkey, the private quality standards in agricultural production, lack of stable market conditions, and high input prices and indebtedness accompanied by increasing prices have led small producers to lose the ability to compete with large producers in the market (Franz, Appel, \& Hassler 2013; Atasoy, 2013; Yenal \& Keyder, 2011). The Aegean region, where subsistence is based on agriculture, has been considerably influenced by these transformations in Turkey. Supermarket's preference for large-scale producers to guarantee stable procurement has caused the gradual impoverishment of small producers and their withdrawal from the market, especially in the Aegean region where private-run farms (including this 
study's case farm) are clustered. My field research reveals the establishment of this farm in the region to have provided significant opportunities for the villagers, who had been left at the mercy of merchants and had limited access to the market because of the supermarket revolution. The farm owner purchases crops produced by small producers in the region at prices relatively higher than merchants' prices. One of the farmers I interviewed said:

In the past, merchants used to come and pay 7 Turkish Lira to buy figs, the price of which is usually 10 lira. Why do I prefer to sell to the farm owner²? She pays 3-5 lira more. For example, tomorrow, I will take some oil to her. I will sell about four kilos of oil for $55 \mathrm{lira} / \mathrm{kg}$, receiving 220 Turkish liras in total. Since the [farm owner] started her business here, merchants have increased their prices as well. ${ }^{3}$

As a result of the recent agricultural transformation in Turkey, both food products' prices and farmers' productive capacities in the region had declined. Farmers in this village were no longer able to work the land they had previously used for production. The decline in production capacity resulted in vast, uncultivated agricultural land, which in turn was used for planting animal feed crops like barley. The study's case farm owner has turned these vacant lands into a tremendous opportunity for her economic growth. She bought these lands to increase her production capacity. In one of the interviews I conducted with her, she said, "I buy new land almost every week" to meet the urban demand for natural food. When a field she has bought remains insufficient for meeting the urban demand, she mobilizes the villagers who have not yet sold to the farm owner to cultivate their soil. The villagers cultivate their land in accordance with the demands of the farm owner. In other words, a year in advance, the farm owner organizes the villagers based on a detailed plan of who will produce what, in what amount. By making an organizational division between villagers, she turns the entire village into a production landscape, in a sense, a factory.

Furthermore, the decline in production capacity had also generated a workforce surplus in the region. The workforce surplus that had emerged as a result of the recent neoliberal transformations has turned the villagers into the employees who work at her farm. Villagers who have been deprived of cultivating their lands are now full-time workers at the farm. More importantly, the owner of the farm not only employs villagers from the hosting village where the farm was established, but she also employs the workforce from the surrounding villages such as Yaylapinar, Has, Hamzalli, and Mastauvra (Bozyurt). The farm offers employment opportunities for the people living in the region.

2 Although the interviewee used the name of the owner here, I replaced it with the term the "farm owner" because of the ethical concerns I mentioned earlier.

3 Interviewee: Ahmet. Please note that all interviewees in this study are presented under pseudonyms. 


\section{The Organizational Structure of the Farm}

This study's case farm was established on 3 acres of land and contains several separate production units that are: the store, shipping, stone-oven bakery, chicken coop, dairy, pastry production unit, kitchen where workers have their lunch, and two office rooms. Each production unit consists of women workers as well as a female chef with a particular speciality.

This farm grows crops on a vast agricultural tract of 148 acres in and around the hosting village. Both seasonal and permanent workers plant, hoe, and harvest the crops in this agricultural land. In addition to the agricultural land, the farm also has a nearby barn with 80 cows, 40 sheep, and 20 goats. However, as the animals' numbers and size of the lands the farm owns are insufficient to meet the demands, she gets supplies of food from the villagers. One villager from Yaylapınar village stated that:

She [the farm owner] recently made a statement in this coffee house. She asked us to grow certain crops, and she would help us. For example, she said if we need water, she will provide us with the necessary equipment and organize the system we need. ${ }^{4}$

She has 150 employees, a vast majority of whom are women. The workforce consists of permanent and seasonal workers. The permanent jobs include office work, packing, cleaning, and cooking at the farm. Full-time workers the minimum wage, except for the agricultural engineer, the manager, and the order takers who hold high positions at the farm. The seasonal workers either work in the field during specific periods like harvest and hoeing, or work from home doing jobs such as scooping out eggplants, cracking walnuts, and stringing peppers to dry. Around six hundred different kinds of raw and manufactured products are produced by these workers and are listed weekly in an Excel table for the email group of consumers. The salaries of seasonal workers vary depending on the work they perform. In her interview, the farm owner said:

In addition to full-time jobs, the farm employs seasonal workers. Many people benefit from us. I kept coming up with side jobs they could do as a family in their homes such as threading and drying peppers and eggplants [...] For example, we do not expose the wheat to photocells. There is a conveyor belt system called Sortex ${ }^{5}$ that could help us extract the stones when we process grain. However, that machine also infuses the wheat with arsenic. Our women instead manually sort grain by the sack. The same goes for lentils. They extract the stones from the grain like it's nothing for them. This provides a decent income for themselves. Not only do they not get tired or cold, but they are also able to do household chores and cooking. They just sit around the wheat and sort it out; that might sound absurd, but it doesn't to me. That is precisely what needs to be done. Nothing is stopping me from using Sortex, but that's not the issue [...] Even women in their $60 \mathrm{~s}, 70 \mathrm{~s}$, or $80 \mathrm{~s}$ should be extracting stones from wheat right now. ${ }^{6}$

4 Interviewee: Yusuf.

5 Sortex is a machine that sorts out the variant from wheat or rice. It standardizes the color and size of crops.

6 Interviewee: farm owner. 
While non-disabled people are employed as full-time workers at the farm, children and seniors appear to work from home. The farm owner utilizes both the villager's labor force and their traditional knowledge and this has been necessary for production since the farm was established. What has enabled the owner, a woman who grew up in a middle-class family in Istanbul, to constantly scale up the farm's production capacity without any insights about agricultural production is the local knowledge the villagers in the region have provided. The farm owner describes her beginnings as follows:

We kicked off in the tiny village made up of 14 households. Each of my neighbors became part of this structure. Their neighbors, children, elderly and men... One by one, each person in the region became a member of the farm. I owned the land, and they had the knowledge [...] We started working together. The marketing techniques were new age; everything that has been hollowed out, discredited, and forced into categories remained far away from us. We did not pay attention to our surroundings, only to what is ahead. We literally put our backs into it. In the brief period of about a year that I had lived in this village, everything went back to the way it was 50 years ago. The boundaries between our cars, houses, and fields were lifted. Every inch of the fields that had remained unplowed for decades because it did not yield profit was sown with the heirloom seeds of Anatolia. Every beauty that had faded away was revived, rejuvenated. It was extremely well received and appreciated. ${ }^{7}$

Two fundamental themes appear in this description: 1) by appropriating both the knowledge and labor, as well as by cultivating previously unused fields with local seeds, the village along with all of its resources has been converted into an integral part of the capital accumulation process. 2) The nature, soil, labor force, and local knowledge of the villagers have all become the means for consolidating a particular form of value extraction. Furthermore, the owner built guest houses for her customers at strategic points with beautiful views in one of the surrounding villages. By staying in these houses for a certain fee, customers are offered the opportunity to escape the chaotic atmosphere of the city for a few days and can be "in touch with natural life" while also satisfying their curiosity about the physical and hygienic conditions of the farm where they purchase their food. Consequently, capital has taken over every aspect of life in the village in order to meet the demands of middle classes in distant cities; the entire village has been converted into units of value creation.

\section{Appropriating Women's Domestic Labor and Knowledge}

Women have rich insights about every aspect of producing life because of their role in everyday life (Sachs, 1996). In their daily activities, women in rural areas have contact with plants, animals, land, and water in addition to humans. These connections have enabled them to possess detailed knowledge about "soil types, soil toxicity and salinity conditions, water sources and fluctuating water level and different seeds and

7 Interviewee: farm owner. 
their sustainability for various ecological and labor conditions" (Sachs, 1996, p. 92). Women's work in rural areas, such as gathering fuel, fodder, and water and cultivating food for their families' subsistence, places them in a particular relationship with the natural environment (ibid). The material relationship women have with nature provides them with a particular perspective and a specific form of knowledge. This specific knowledge and perspective do not arise from women's symbolic or essential connections to nature but rather from their distinct material relations to the natural world (p. 41).

Environmental activist and scholar Vandana Shiva showed how women's knowledge of plants and soils, and thus the production of life, has been appropriated through the regimes of new intellectual property rights imposed by the Trade-Related Intellectual Rights Agreement (TRIPs) of the World Trade Organization (WTO). According to Shiva (2001, p. 13) based on the case of India, "Women have long been the biodiversity experts, whether as seed keepers or as healers: the knowledge of plants and their uses has been women's knowledge." She says that this knowledge is now the means for capital accumulation imposed by intellectual property rights (IPRs). Similarly, feminist scholar Federici (2004) underlined how appropriating women's knowledge has been embedded from the very beginning in the rise of the capitalist economy. Women's collective knowledge as midwives and healers, traditional roles corresponded to what we would now classify as medicine, gynecology, and psychotherapy. The period of capitalist ascendancy realized that all these women's independent knowledge about the body and life provided them with considerable power. Therefore, capitalism from its inception has required the destruction of women's control over their knowledge by transferring it into the hands of professionalized groups of people. The rise of the capitalist economy and the subsequent accumulation of wealth cannot be isolated from women's forms of knowledge. The direct relation between capital accumulation and women's labor and knowledge has taken different shapes in various historical periods and sectors. This paper seeks to understand how this relationship has progressed, specifically in the non-certified commercial natural food sector.

Such analyses move beyond the hegemonic concept of economy that associates the economy only with the domain of scientific or professionalized knowledge. Henry and Pollard (2000) claimed the economy to be much broader than any particular economic rationale. Economy encompasses the whole range of behaviors driven by the everyday activities of a social being. This is an alternative conceptualization of economy. The economy cannot be analyzed as an analytically distinct sphere separate from society. Hence, no pure, completely rationalized economic model exists in the way the mainstream approach would suggest. Economy has always been embedded in both economic and non-economic institutions, experiences, and actions (Granovetter, 1985). The feminist literature on women's domestic labor argues women's domestic labor, including their care labor, cooking, and many other reproductive works, to have 
always been a constitutive element of diverse forms of capitalist accumulations (Federici, 2004; James \& Dalla Costa, 1973; Mies, 1998). Capital owners transform an enormous quantity of social services into a privatized activity, one that women should perform at home (Dalla Costa \& James, 1973, p. 14). The social services provided at home reproduce the labor power for the following workday. Therefore, a larger amount of labor is present than appears in the factory or is embedded in men's wages. In other words, women's domestic un-paid labor is a constitutive yet obscure element in capitalist formations. The constitutive role of women's labor and knowledge diversely manifests itself depending on the economic sector. I argue that the noncertified natural food sector is one of these sectors where women's knowledge (especially their culinary knowledge) and labor are two constitutive elements that have been obscured in the economic growth of non-certified farms.

Before working as a laborer at the farm, women in the host and surrounding villages had been involved in the food cycle all year round. They were in touch with the plants, animals, soil, and water on their lands and were involved in the culinary production from the crops they obtained from these lands. Their culinary production consisted of both daily foods and long-lasting products such as fruit compost, tarhana, salça (tomato or pepper pastes), mantı (similar to tortellini), yufka (flat bread). I would like to define these as craft products because their knowledge and skills as well as experience are required for their production. These women were therefore involved in the production and reproduction of life itself. The material relationship these women had with life provided them specific knowledge and skills. This skills and knowledge they acquired while producing life have made women invaluable assets for this study's farm owner. The farm manager explains employing women as:

We write down the qualities of those who apply for a job (many people from the surrounding villages apply for a job, sometimes they hear it from their neighbors). We note what they can do. For example, I ask, "What do you like doing most at home? Do you like baking cakes or other pastries? Do you like cleaning? Do you like preparing tarhana?" ${ }^{8}$ In this way, you get to know the person, what she likes. For example, in my notes, I write down such information as "This person rolls dough very well."

The farm manager categorizes the women applying for work according to their skills and aptitudes and then employs them in the production of about 600 different products. For example, if a woman is good at making cakes or cookies, she would be placed in the bakery. If she is good at making bread, then she would be employed at the stone oven. Although the skills women have gained throughout their lives make them wage laborers at the farm, the manager disqualifies their labor, saying that:

8 Tarhana is the name of a soup made from a fermented mixture of grain and yogurt.

9 Interviewee: Handan. 
$90 \%$ of the people who work here did not go to university. And probably very few of them went to high school. Most of them only went to primary or junior high. They are all brilliant people, but they are not skilled employees. I mean, for example, pastry chefs have been trained on cakes, so they know everything from how to make it to how many calories it has and what ingredients are involved. I mean, they are a bit like a professional. But the employees here are not like that. Of course, they know what to do, but they have learned it from their mothers, fathers, neighbors, or friends. ${ }^{10}$

Although the food products obtain their authentic quality from the non-professional character of women's labor, the manager defines this as unskilled, worthless, and inferior. I claim that the tendency towards disqualification owes to the unpaid character of women's domestic labor. Federici (2004, p. 94) showed how disqualifying any work women carry out in the paid-wage workforce is directly related to their function as unpaid laborers in the household. She argues that, because any work women perform at home is defined as "non-work," they are viewed as worthless even when doing this work for the market (pp. 94-95). The inferior quality attributed to their labor results in women being paid minimum wage at the farm. The growth of capital, however, does not merely depend upon its capacity to extract surplus. As Harvey (2006, p. 90) contended, "It rested, rather, upon its ability to appropriate them, treat them as their private property and launch them into circulation in search of further surpluses." At this study's case farm, I observed that women are not paid for certain items of work, and they are always being imposed with some extra tasks as these tasks are perceived as women's natural duty. In an interview I conducted with a worker, she said:

When the customers come to the village house, I am asked to pause from making bread, which is my profession at the farm, and assist the incoming guests. I try to provide all their services, but I cannot complete everything. I have asked for a helper, but they do not do it. My sister has helped me many times, or I ask for help from my neighbor in the village, but they do not get paid for this. ${ }^{11}$

Women know specific techniques for both cooking and preserving food (canning, freezing, and drying). They have acquired this knowledge in their daily practices, not from working on the farm itself or by attending various professional courses. My fieldwork reveals that the farm owner has transferred all the knowledge accumulated from the women's life experiences and inherited from previous generations into the farm without any cost. This is exactly what I mean by how the sector appropriates women's culinary knowledge. This is overtly evident in the following statement from the farm manager:

These women are total creators. Why do you think we have gained 7-8 kilos within two years? (Laughs) For example, take Melek. She comes every other day with a plate in her hand, saying "I made this, and I made that." It depends on what we have at hand. Let's say it's the apple or apricot season. $90 \%$ of our posts are to Istanbul, so they must be packaged very carefully. If an

10 Interviewee: Handan.

11 Interviewee: Aysel. 
apricot has a wormhole or a small puncture, then the juice of that apricot gets to the others and causes them to go bad. Therefore, we put the products with small punctures or bugs aside. So, when we have some apricots or peaches, what do we do? We make jams or marmalades with them. We don't waste any product. Even the worst ones [...] We feed our animals with them. All of us, say, our friends, us, or the farm owner [...] We think about what we can do. We use pumpkin, for example, if it is in season. Ayşe made a pumpkin pie the other day; we tasted it, and it was wonderful. They come and say "Handan Hanım, I saw this, this is beautiful, let's mix our cheese with this thing, and it will be wonderful." They make it, and we eat it. The farm owner eats it and says, "Oh, this is good," so we add it to the list. There is a non-professional R\&D here, and actually, it is the best. ${ }^{12}$

The term research and development $(R \& D)$ is quite ironic here. $R \& D$ is a general term for activities that are conducted to make a discovery that can either lead to the development of new products or procedures or the improvement of existing products or procedures. ${ }^{13}$ It is a means through which new types of knowledge are produced or improved for furthering business growth. The women on this farm come every other day with new ideas and suggestions using their knowledge about domestic food production. They create unique recipes instead of depending on readymade or standardized recipes. Their knowledge turns into a means of capital accumulation in the sector of natural food production.

\section{Romanticizing the Past as a Discursive Strategy in Value Creation}

The owner sees her farm as an alternative to certified organic farm products that she says are dependent on the seed monopolies and agro-food production controlled by global food corporations and global financial and commercial institutions. She suggests that her production methods and her unique perspective on natural food and farming considerably differ from organic agricultural production:

I did not get certified because it was meaningless to me. First, what I do here is not commercial. It is a hobby that started after the birth of my daughter to feed her healthy food [...] It is appreciated, it has become a bigger issue, but it is still only a hobby [...] I am not concerned about proving my products. I just follow the same way our grandparents in these mountain villages produced for centuries the most organic of all organic products. My production is the same as has been done in these lands for thousands of years by real heirloom seeds and manure. ${ }^{14}$

She starts with the claim that she engages not in commercial but alternative farming. This notion of alternativeness lies on an ethic that does not need to be proved by any kind of certification. This ethic, in her opinion, requires one only to apply the agricultural methods transmitted from the past. If a producer uses the old methods, then the products produced become organic, natural, and healthy automatically. However, she does not

12 Interviewee: Handan.

13 See http://www.investopedia.com/terms/r/randd.asp

14 Interviewee: farm owner 
offer any concrete data to compare the production practiced on the farm with certified organic production. An assumption is hidden in this perspective: Keeping the agricultural practices transmitted from the past is the best way to achieve what is natural.

The criticisms toward certified food production do not just revolve around health issues. They are also accompanied by a more comprehensive and critical discourse addressing the destructive impact modern agriculture techniques and industrialism have on natural life. The critical discourse seen on this farm is based on a romanticism places nature opposite the city and the pastoral world opposite today's modern world. The logic of modernism and capitalism, which values the new over the old, is reversed here. The old becomes a source of value. Providing natural food is pictured as if it is a return to the earlier times associated with essence, originality, and genuineness (Taylor, 2001). In the industrial world, the thought is that we are far removed from originality. We live in an artificial world in which we are subject to machine-made products that are inauthentic and lifeless. The products produced by these initiatives, however, are claimed to be "hand-made" from natural materials. In this logic, rejecting the newest and the most contemporary is the way to remain authentic (i.e., original and genuine), and making this preference adds much more value to the products.

Despite the varying definitions, romanticism implies a reaction against the modern values that seek to destroy the ideals drawn from the past (Löwy \& Sayre, 2001, p. 17). From a romantic perspective, the past consists of the idealized values systems that contemporary modern practices are deemed to be abolishing. No new value brought by the modern world can replace the supreme values of the old in this account. Here the idea is the need to pursue what is being lost in modern times and to revive these to keep the past alive in the present. The sense of loss and the effort to compensate for it prevail in the romantic perspective.

My fieldwork reveals the narrative of natural food initiatives to hinge considerably on representing the "good old days" by apprising the idea that the taste and the quality of food they produce in their farms are the same as had been in the past (Küçük \& Soysal $\mathrm{Al}, 2019, \mathrm{p} .181)$. This idea is reinforced by constantly evoking the memory, values, and practices of the past. They offer their customers a chance to re-appropriate what has been lost in their current food consumption. These are the tastes, smells, and qualities that existed once upon a time but have been lost in the present. Their customers are invoked to chase the dream of the taste and smell of foods that have been imprinted on their memory (Küçük \& Soysal Al, 2019, p. 182). Evoking the memory of the past appears as a recurring theme in the farm owner's narrative and serves for building trust. This explicitly appears in one of the narratives the farm owner emailed to her followers:

The equation is simple, and the demand is clear: "We wish everything to be the way it was in our childhood." These words have a very deep meaning for me. I had the happiest days of my life in 
my childhood. The couch I liked most, my favorite bath, the kitchen where I was the happiest, the smell of the food coming from the pot [...] I haven't heard voices more pleasing than the voices of my mother, father, and brother heard at home. I could never sleep as well as I could sleep among their voices back then [...] The words that stuck in my mind back then are repeated in these words. ${ }^{15}$

The farm owner selects a moment from her childhood and idealizes it as an experience of absolute happiness. She associates the most memorable moments of family life with delicious foods and the kitchen. In this quotation, she not only evokes the memory of taste but also of the related items (family members' voices, furniture, and bathing) that reminds one of the tastes of food. She promises her customers such a nostalgic life experience through her food. Consequently, the promise of taste she offers is followed by the promise of a life experience far removed from the destructive character of the industrial world. Here, such a promise sticks to the exchange value of food and turns into a product differentiation strategy. This strategy is accompanied by a reaction against the new methods and techniques, as the following quote retrieved from the interview conducted with the farm owner illustrates:

We have not included anything from the new age. We have not had a single advertisement, have not received a single penny from bank credits, and haven't ever used the social media of the age. We trust only to our hands and the work which we believe we do properly. ${ }^{16}$

A closer look at the processes from production to distribution at the farm reveals the farm to be a modern large-scale agricultural enterprise. This enterprise is completely based on modern electronic sales techniques and new Internet technologies: The customers are informed by an online channel, allowed to pay online, and delivered their products by cargo companies. The farm even has a website. Despite these contemporary techniques and technologies, she creates an impression of an authentic past in each step from production to distribution. She achieves this by developing an immediate and sincere language; by also standing in the face of the new, she appears to prioritize ethics over profit. This has a great impact on customers, compared to the cold, artificial language of modern commerce. Sublimation of elements from the past is also evident in the following email:

We use only Anatolian wheat seeds dating before the 1950s because their gliadin structure has not been modified. For bread, we use the sourdough from one of the surrounding villages, dating back to chickpea yeast from the 16th century. Our tables have regained the delights we had 50 years ago. ${ }^{17}$

The more she refers to the distant past, the more her products gain value. In this way, she generates the concept of genuine food, which implies the unchanged and

\footnotetext{
15 Interviewee: farm owner

16 Interviewee: farm owner.

17 Interview, farm's owner.
} 
untouched character of the food produced on her farm. She proposes genuine food by avoiding the use of artificial fertilizers, pesticides, and contemporary marketing strategies. She constructs the concept of genuineness, which implies that the food and the way it is produced has remained unchanged and untouched. The idea of sustaining the production methods inherited from the past and preserving the essence of food by avoiding the use of chemicals is apparent in her following statement:

The sourdough that we use is literally the same as the one used since the 1500 s when the village that supplies our sourdough was settled. The mastery has also been transferred from generation to generation in the same cycle. Here the piecework is told simply. Events that are supposed to be told by hundreds of photos and pages goes something like this: "My grandma's grandma used to have this sourdough [...] The sourdough is handed down from generation to generation. The generations have passed; this yeast still comes to life in each home and every loaf of bread by refreshing and recirculating itself. It departs from there to find its path to come to your table in Bebek, Kemerburgaz, and Ataşehir." ${ }^{18}$ If there is something surprising, this is it for me.

Asking how the farm's production capacity can grow at an ever-increasing rate by avoiding the use of agricultural chemicals and preserving the old methods, seeds, and yeast is a worthwhile question. Meeting the continually increasing demand for natural food by using the old methods based on the logic of self-sustainability seems impossible. This obvious truth is surrounded by various discursive strategies such as product differentiation and thus the mechanism of value creation. One of the ideas of this paper is that romanticizing the past constitutes an integral part of the product differentiation and thus the value creation processes.

A leitmotif appears in her narratives: All the techniques and procedures for cultivating, planting, baking, cooking, and such come from the past, have been handed down from generation to generation, and guarantee the quality of products. In this way, the products differ from ordinary industrialized ones. Therefore, products from this farm gain a natural character. What is presumed as natural depends on it having been passed down from the past. Idealizing the past, or forming a utopia of it, is an integral part of the romantic vision (Löwy \& Sayre, 2001, p. 249). After being idealized, the past turns into an image that is applied to food and that identifies it as being natural. In other words, this provides a framework for guaranteeing food's naturalness and generates particular qualities for food. Among many strategies, the product differentiation strategy that romanticizes the past what make the farm owner a privileged producer.

\section{Conclusion}

In this article, I have examined the role women's knowledge and labor and discursive strategies have in the mechanisms of value creation and product differentiation, which in turn have resulted in capital accumulation in natural food production in Turkey. 
Relying on the fieldwork carried out in a farm located in the Aegean region that represents the general characteristics of newly emerging farms in Turkey, I argue that women's domestic labor and knowledge and various discursive strategies constitute significant elements of capital accumulation in the natural food sector.

First of all, I consider this farm to be an effect of the transformations in the agro-food sector, both at the local and global levels. Agricultural transformations in Turkey have led to a decrease in the production capacity of small farmers in rural areas. In turn, this has resulted in huge tracts of land to remain uncultivated and a labor surplus to emerge. This study shows that one private farm entrepreneur has expanded her production capacity by transferring all these agricultural transformations to her own benefit.

After providing this framework, I have analyzed the labor relations in the sector of natural food production. Women receive minimum wage for their labor in this sector. However, a large part of their labor and knowledge is included unpaid in production. I have discussed the feminist perspective that relates the unpaid and low paid character of women's labor in the workforce with their position in the household. In terms of their knowledge, I have attempted to show how the farm owner has appropriated the women's culinary knowledge, knowledge of nature acquired through their reproductive activities at home, and distinctive relations to the natural world outside of home, treating this as the farm owner's private property. This appropriation simply cannot be reduced to the neoliberal transformations I discussed at the beginning of the paper. Women's labor and knowledge have always become an integral part of capital accumulation, especially in the women-intensive sector. Yet, in this study, I have attempted to reveal how this appropriation has been made possible in Turkey's newly emerging natural food sector. Although neoliberal dynamics in agro-food are not the only explanatory factor in this appropriation, they have nevertheless had a huge impact on changes in the processes of owning land and laboring. In this way, I have also aimed to reveal the continuity of this appropriation through a different face of capitalist accumulation in agriculture.

In addition to material production, I have also elaborated on the discursive production of food, which is essential for product differentiation under competitive market conditions. By analyzing the narratives, the farm owner creates weekly for her customers, I have revealed the prominent themes she applies to food to increase its value. I argue that, rather than a set of objective criteria, food gains a natural character through various narratives such as romanticizing the past. The glorification of all kinds of past values, including mothering practices, production methods, and past tools in addition to taste and smell assure the natural character of food in the natural food sector. 
Peer-review: Externally peer-reviewed.

Conflict of Interest: The author declares no potential conflicts of interest with respect to the research, authorship, and/or publication of this article.

Grant Support: The author received no financial support for the research, authorship, and/or publication of this article.

\section{References}

Agrawal, A. (1995). Dismantling the divide between indigenous and scientific knowledge. Development and Change, 26(3), 413-439. https://dx.doi.org/10.1111/j.1467-7660.1995.tb00560.x

Agrawal, A. (2002). Indigenous knowledge and the politics of classification. International Social Science Journal, 54(173), 287-297. https://dx.doi.org/10.1111/1468-2451.00382

Appadurai, A. (Ed.). (1988). The social life of things: Commodities in cultural perspective. Cambridge University Press.

Atasoy, Y. (2013). Supermarket expansion in Turkey: Shifting relations of food provisioning. Journal of Agrarian Change, 13(4), 547-570.

Aydin, Z. (2010). Neo-liberal transformation of Turkish agriculture. Journal of Agrarian Change, 10(2), 149-187. https://dx.doi.org/10.1111/j.1471-0366.2009.00241.x

Buck, D., Getz, C., \& Guthman, J. (1997) From farm to table: The organic vegetable commodity chain of Northern California. Sociologia Ruralis, 37(1), 3-20.

Burch, D., \& Lawrence, G. (2007). Understanding supermarkets and agri-food supply chains. In authors (Eds.), Supermarkets and agri-food supply chains (pp. 1-26). Edward Elgar Publishing.

Cáceres, D. (2005). Non-certified organic agriculture: an opportunity for resource-poor farmers? Outlook on Agriculture, 34(3), 135-140.

Çağlar, K., \& Zafer, Y. (2013). Bildiğimiz tarımın sonu: Küresel iktidar ve köylülük. İletişim Yayınları.

Dalla Costa, M., \& James, S. (1975). The power of women and the subversion of the community. Falling Wall Press.

Dixon, J. (2007). Supermarkets as new food authorities. In D. Burch \& G. A. Lawrence (Eds.), Supermarkets and agri-food supply chains (pp. 29-50). Edward Elgar.

Escobar, A. (1999). After nature: Steps to an antiessentialist political ecology. Current Anthropology, 40(1), 1-30. https://dx.doi.org/10.1086/515799

Federici, S. (2004). Caliban and the witch. Autonomedia.

Feldman, S., \& Welsh, R. (1995). Feminist knowledge claims, local knowledge, and gender divisions of agricultural labor: Constructing a successor science. Rural Sociology, 60(1), 23-43. https:// dx.doi.org/10.1111/j.1549-0831.1995.tb00561.x

Franz, M., Appel, A., \& Hassler, M. (2013). Short waves of supermarket diffusion in Turkey. Moravian Geographical Reports, 21(4), 50-63.

Friedmann, H. (1990). Food question: Profit versus people? In H. Bernstein, B. Crow, M. Mackintosh, \& C. Martin (Eds.), The origins of Third World food dependence (pp. 13-31). Monthly Review Press.

Friedmann, H. (2005). From colonialism to green capitalism: Social movements and emergence of food regimes. In New directions in the sociology of global development (pp. 227-264). Emerald Group Publishing Limited. https://dx.doi.org/10.1016/S1057-1922(05)11009-9

Gereffi, G., \& Korzeniewicz, M. (Eds.). (1994). Commodity chains and global capitalism (No. 149). ABC-CLIO. 
Gereffi, G., Humphrey, J., \& Sturgeon, T. (2005). The governance of global value chains. Review of International Political Economy, 12(1), 78-104.

Goodman, D., \& Goodman, M. K. (2007). Localism, livelihoods and the 'post-organic': Changing perspectives on alternative food networks in the United States. In: D. Maye, L. Holloway, \& M. Kneafsey (Eds.), Alternative food geographies (pp. 23-39). Elsevier.

Granovetter, M. (1985). Economic action and social structure: The problem of embeddedness. American Journal of Sociology, 91(3), 481-510. https://dx.doi.org/10.1086/228311

Guthman, J. (1998). Regulating meaning, appropriating nature: The codification of California organic agriculture. Antipode, 30(2), 135-154. https://dx.doi.org/10.1111/1467-8330.00071

Harvey, D. (2006). Spaces of global capitalism. Verso.

Jordon, S., \& Shuji, H. (2004, July 25-30). Conventionalisation of the Australian organic industry. Paper presented at XI IRSA World Congress. Trondheim, Norway.

McMichael, P. (1996). Development and social change: A global perspective. Pine Forge Press.

Mies, M. (1998). Patriarchy and accumulation on a world scale: Women in the international division of labor. Zed Books.

Molyneux, M. (1979). Beyond the domestic labor debate. New Left Review, 116(3), 27.

Reardon, T., \& Hopkins, R. (2006). The supermarket revolution in developing countries: Policies to address the emerging tensions among supermarkets, suppliers and traditional retailers. The European Journal of Development Research, 18(4), 552-545.

Shiva, V. (2001). Special report: Golden rice and neem: biopatents and the appropriation of women's environmental Knowledge. Women's Studies Quarterly, 29(1/2), 12-23.

Soysal Al, İ. (2017). Quotidian realities of organic mothering in Turkey. New Perspectives on Turkey, 57, 61-84. https://dx.doi.org/10.1017/npt.2017.29

Soysal Al, I., \& Küçük, B. (2019). In-between Anxiety and Hope: Trusting an Alternative Among 'Alternatives' in the (Post) Organic Food Market in Turkey . The International Journal of Sociology of Agriculture and Food, 25(2), 173-190. Retrieved from https://ijsaf.org/index.php/ijsaf/article/ view/42

Yenal, D., \& Yenal, N. Z. (1993). The changing world food order: The case of Turkey. New Perspectives on Turkey, 9, 19-46. https://dx.doi.org/10.1017/S089663460000220X

Yenal, N. Z. (2001). Türkiye'de tarım ve g1da üretiminin yeniden yapılanmas1 ve uluslararasılaşması. Toplum ve Bilim, 88, 32-54. 
